Check for updates

Cite this: RSC Adv., 2017, 7, 24933

\title{
Photoelectrocatalytic reduction of carbon dioxide to methanol at cuprous oxide foam cathode
}

\author{
Jiongliang Yuan, (D) *a Xuan Wang, ${ }^{a}$ Chunhui Gu, ${ }^{\text {b }}$ Jianjun Sun, ${ }^{\text {b Wenming Ding, }}{ }^{\text {b }}$ \\ Jianjun Wei, ${ }^{a}$ Xiaoyu Zuo ${ }^{b}$ and Cunjiang $\mathrm{Hao}^{\mathrm{c}}$
}

In order to increase the reduction rate of $\mathrm{CO}_{2}$ to methanol, the photoelectrocatalytic reduction of $\mathrm{CO}_{2}$ at $\mathrm{Cu}_{2} \mathrm{O}$ foam electrodes is proposed. The $\mathrm{Cu}_{2} \mathrm{O}$ foam electrodes are fabricated by electrodeposition of $\mathrm{Cu}_{2} \mathrm{O}$ coatings on copper foam substrates. The effect of bath $\mathrm{pH}$ and deposition time on the morphology and structure is investigated. The $\mathrm{Cu}_{2} \mathrm{O}$ foam electrodes deposited at bath $\mathrm{pH} 10$ for $20 \mathrm{~min}$ exhibit higher intensity of (111) diffraction peak. The photoelectrocatalytic performance of $\mathrm{Cu}_{2} \mathrm{O}$ foam electrodes for $\mathrm{CO}_{2}$ reduction to methanol depends largely on exposed $\mathrm{Cu}_{2} \mathrm{O}\{111\}$ facets. At the applied potential of $-1.5 \mathrm{~V}$ (vs. saturated calomel electrode), the optimum methanol concentration and the faradaic efficiency of methanol formation are obtained within $1.5 \mathrm{~h}$, and they are $1.41 \mathrm{mM}$ and $29.1 \%$, respectively. The formation rate of methanol achieves $23.5 \mu \mathrm{mol} \mathrm{cm} \mathrm{cm}^{-2}$ within $1.5 \mathrm{~h}$.

Received 22nd March 2017 Accepted 3rd May 2017

DOI: $10.1039 / \mathrm{c} 7 \mathrm{ra} 03347 \mathrm{~h}$

rsc.li/rsc-advances surface, methanol production rate as high as $43 \mu \mathrm{mol} \mathrm{cm} \mathrm{cm}^{-2} \mathrm{~h}^{-1}$ and faradaic efficiency up to $38 \%$ within $10 \mathrm{~min}$ have been reported; however, the activity of $\mathrm{Cu}_{2} \mathrm{O}$ electrode decreases suddenly, and the reduction reaction of $\mathrm{CO}_{2}$ to methanol stops within $30 \mathrm{~min} .{ }^{14}$ In order to improve the stability of $\mathrm{Cu}_{2} \mathrm{O}$ electrodes, $\mathrm{Cu}_{2} \mathrm{O} / \mathrm{ZnO}$-based carbon paper electrodes have been fabricated. ${ }^{15}$ The electrodes including $\mathrm{ZnO}$ are stable after $5 \mathrm{~h}$, but the rate of methanol formation is only $11.41 \mu \mathrm{mol} \mathrm{cm} \mathrm{cm}^{-2} \mathrm{~h}^{-1} .^{15}$

Both photochemical and electrochemical routes have low yield of methanol. ${ }^{1}$ In photoelectrochemical system, the separation of light-driven electrons and holes in the semiconductor catalysts is promoted, and the reduction and oxidation reaction zones are fully separated; therefore, the yield and selectivity of methanol is enhanced. ${ }^{\mathbf{1}}$ In addition, compared to electrochemical route, photoelectrochemical route can reduce the consumption of external electric energy. ${ }^{1}$ In our previous study, the photoelectrochemical reduction of $\mathrm{CO}_{2}$ to methanol at $p$ type $\mathrm{CuInS}_{2}$ thin film photocathode has been proposed, with the overpotential of $20 \mathrm{mV}$ and the faradaic efficiency of $97 \%{ }^{\mathbf{1 6}}$ however, due to the mass transfer resistance resulting from pyridine adsorption layer on $\mathrm{CuInS}_{2}$ electrode, the rate of methanol formation is only $5.9 \mu \mathrm{mol} \mathrm{cm}{ }^{-2} \mathrm{~h}^{-1} \cdot{ }^{17}$

Copper foam has large surface area, well-defined pore size and high conductivity, it is therefore a better support for catalysts than conventional planar supports. It is expected to improve the catalytic performance of $\mathrm{Cu}_{2} \mathrm{O}$ for $\mathrm{CO}_{2}$ reduction by loading $\mathrm{Cu}_{2} \mathrm{O}$ catalysts on copper foam support. In this study, $\mathrm{Cu}_{2} \mathrm{O}$ foam electrodes are fabricated and their photoelectrocatalytic performance for $\mathrm{CO}_{2}$ reduction to methanol is examined.

\footnotetext{
${ }^{a}$ Department of Environmental Science and Engineering, Beijing University of Chemical Technology, Beijing 100029, P. R. China. E-mail: yuanjiongliang@163.com; Tel: +86 1064427356

${ }^{b}$ College of Chemical Engineering, Beijing University of Chemical Technology, Beijing 100029, P. R. China

${ }^{c}$ Department of Experimental Teaching, Tianjin University of Traditional Chinese Medicine, Tianjin Key Laboratory of Chemistry and Analysis of Chinese Materia Medica, Tianjin 300193, P. R. China
} 


\section{Experimental}

\subsection{Fabrication of $\mathrm{Cu}_{2} \mathrm{O}$ foam electrodes}

$\mathrm{Cu}_{2} \mathrm{O}$ foam electrodes were fabricated by electrodeposition of $\mathrm{Cu}_{2} \mathrm{O}$ coatings on copper foam substrates. A copper foam with the thickness of $0.5 \mathrm{~mm}$ was firstly cleaned by sonicating in detergent, acetone and ethanol in turn, then etched in diluted sulphuric acid, and finally cleaned with deionized water. The copper foam $\left(2 \mathrm{~cm}^{2}\right)$ was used as the working electrode for electrodeposition. A platinum foil and a saturated calomel electrode (SCE) were used as the counter electrode and reference electrode, respectively. The electrodeposition was carried out by a CHI650D electrochemical workstation (Shanghai Chenhua Instrument Co. Ltd., Shanghai, P. R. China). The electrodeposition bath contained $0.4 \mathrm{mM} \mathrm{CuSO}_{4}$ and $3 \mathrm{M}$ lactic acid (LA), and was adjusted to $\mathrm{pH}$ 9-12 by adding $\mathrm{NaOH}$ aqueous solution. ${ }^{\mathbf{1 4 1 8 , 1 9}}$ The bath temperature was kept at $60{ }^{\circ} \mathrm{C}$ during electrodeposition, and the deposition potential was set to be $-0.60 \mathrm{~V}$ (vs. SCE).

The morphology of $\mathrm{Cu}_{2} \mathrm{O}$ foam electrodes was determined by field emission scanning electron microscopy (FESEM, S-4700, Hitachi, Japan). The crystal structure of thin films was determined by X-ray diffractometry (XRD, Bruker D8 Advance, Germany) using $\mathrm{Cu} \mathrm{K} \alpha$ radiation $(\lambda=1.54056 \AA)$, and the crystal grain size was then calculated from $\mathrm{X}$-ray line broadening using the Scherrer's equation. The UV-vis spectra of $\mathrm{Cu}_{2} \mathrm{O}$ foam electrodes were measured with UV-vis-NIR spectrophotometer (UV3600, Shimadzu, Japan), and the scanning wavelength was ranged from 400 to $700 \mathrm{~nm}$.

The measurement of Mott-Schotty plot was carried out at 10 $\mathrm{kHz}$ in a quartz glass beaker containing $0.1 \mathrm{M} \mathrm{KHCO}_{3}$ solution by an electrochemistry work station CHI650D. A standard threeelectrode arrangement was used with $\mathrm{Cu}_{2} \mathrm{O}$ foam electrodes (2 $\mathrm{cm}^{2}$ ) as the working electrode, graphite sheet as the counter electrode and SCE as the reference electrode. The scanning potential was set from -0.25 to $0.40 \mathrm{~V}$ ( $v s$. SCE). The visible light irradiation was emitted from xenon lamp (AULTT, Beijing, P. R. China) with the irradiation intensity of $100 \mathrm{~mW} \mathrm{~cm}^{-2}$ on the surface of the thin film electrode. In Mott-Schotty plot, the extrapolated linear portion where the line crosses the $x$-axis could be used to calculate the flat band potential by the formula

$$
C^{-2}=\left(2 / e \varepsilon_{0} \varepsilon A^{2} N_{\mathrm{A}}\right)\left(E-E_{\mathrm{fb}}-K t / e\right)
$$

where $C$ is the interfacial capacitance, $e$ is electron charge, $\varepsilon_{0}$ is vacuum dielectric constant, $\varepsilon$ is dielectric constant, $A$ is the surface area of the working electrode, $N_{\mathrm{A}}$ is doping concentration of the semiconductor, $E$ is the applied potential, $E_{\mathrm{fb}}$ is the flat band potential, $K$ is Boltzman's constant, and $t$ is the absolute temperature.

\subsection{Photoelectrocatalytic reduction of $\mathrm{CO}_{2}$}

$\mathrm{CO}_{2}$ reduction experiments were performed in a quartz glass beaker by electrochemistry work station CHI650D. A conventional three-electrode cell was used with $\mathrm{Cu}_{2} \mathrm{O}$ foam electrode (2 $\mathrm{cm}^{2}$ ) as the working electrode, graphite sheet as the counter electrode and SCE as the reference electrode. The irradiation intensity on the working electrode was calibrated to be $100 \mathrm{~mW}$ $\mathrm{cm}^{-2}$.

The electrolyte solution used for the photoelectrocatalytic reduction of $\mathrm{CO}_{2}$ was $0.1 \mathrm{M} \mathrm{KHCO}_{3}$ solution $(50 \mathrm{~mL})$. All experiments were performed at $25{ }^{\circ} \mathrm{C}$ and ambient pressure. Prior to the reduction experiment, the electrolyte solution was saturated with $\mathrm{CO}_{2}$ gas $(99.99 \%)$ by bubbling for $30 \mathrm{~min} . \mathrm{CO}_{2}$ gas was continuously aerated at a flow rate of $60 \mathrm{~mL} \mathrm{~min}{ }^{-1}$ during the electrolysis process. The faradaic efficiency for producing methanol was calculated assuming six electrons are required per methanol molecule.

Liquid product analysis was accomplished using gas chromatography-mass spectroscopy (GC-MS, Trace 1300-ISQ, ThermoFisher Scientific, USA). Methanol concentration was measured by a gas chromatography (GC 2014C, Shimadzu, Japan) with a DB-Wax $(30 \mathrm{~m} \times 0.53 \mathrm{~mm} \times 3.00 \mu \mathrm{m}$, Agilent Technologies). The injector temperature was held at $200^{\circ} \mathrm{C}$, the oven temperature rose from 50 to $200{ }^{\circ} \mathrm{C}$ at the rate of $5{ }^{\circ} \mathrm{C}$ $\min ^{-1}$, and the detector temperature was kept at $230^{\circ} \mathrm{C}$. Five runs were done for one experiment.

\section{Results and discussion}

\subsection{Fabrication of $\mathrm{Cu}_{2} \mathrm{O}$ foam electrodes by electrodeposition}

At bath $\mathrm{pH}$ 9-12, $\mathrm{Cu}_{2} \mathrm{O}$ coatings on copper foam substrate can be obtained from a lactate-stabilized $\mathrm{CuSO}_{4}$ solution. The FESEM images of $\mathrm{Cu}_{2} \mathrm{O}$ foam electrodes electrodeposited at bath $\mathrm{pH} 10$ for $30 \mathrm{~min}$ are shown in Fig. 1.

It can be observed that the $\mathrm{Cu}_{2} \mathrm{O}$ foam electrode has threedimensional network structure (Fig. 1a), and copper foam substrate is covered with a $4 \mu \mathrm{m}$-thick-coating (Fig. 1b); in addition, the coaxial structure of outer $\mathrm{Cu}_{2} \mathrm{O}$ coatings and inner copper wire forms (Fig. 1b). Compared to the conventional planar electrode, the three-dimensional network structure of the $\mathrm{Cu}_{2} \mathrm{O}$ foam electrode provides much high specific surface area, which promotes the full contact of the catalytic active centers with the reactants in $\mathrm{CO}_{2}$ reduction. Additionally, the coaxial structure of the $\mathrm{Cu}_{2} \mathrm{O}$ foam electrode promotes the charge transfer between $\mathrm{Cu}_{2} \mathrm{O}$ crystal grains and copper wires.

The electrodeposition bath $\mathrm{pH}$ has a significant influence on the morphology of $\mathrm{Cu}_{2} \mathrm{O}$ coatings as shown in Fig. 2. The surface of $\mathrm{Cu}_{2} \mathrm{O}$ coatings deposited at bath $\mathrm{pH} 9$ and 10 exhibits pyramid and truncated pyramid geometry, respectively. At bath
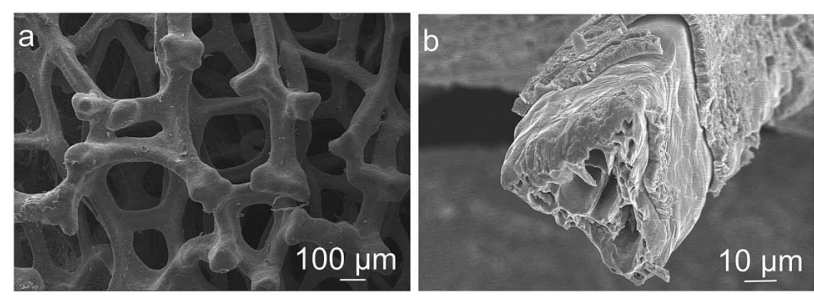

Fig. 1 FESEM images of the $\mathrm{Cu}_{2} \mathrm{O}$ foam electrodes. (a) Full view, (b) cross section view. 

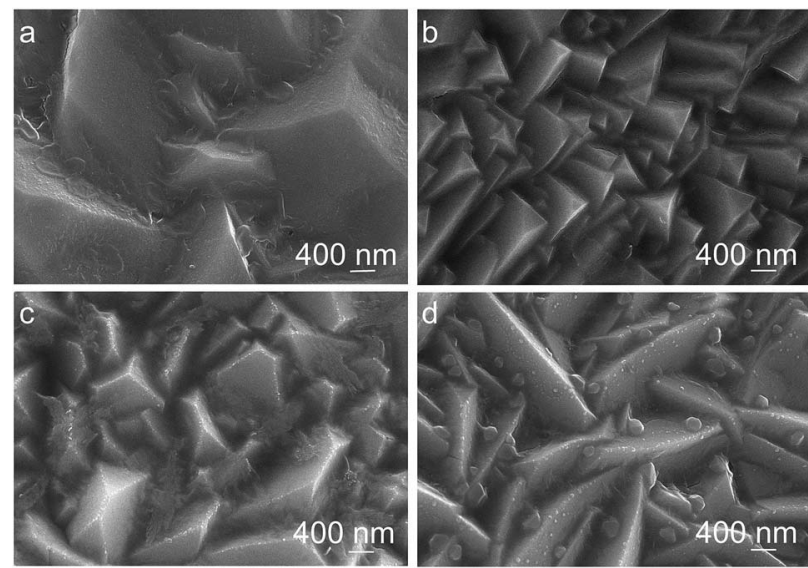

Fig. 2 FESEM image of $\mathrm{Cu}_{2} \mathrm{O}$ coatings electrodeposited at various bath $\mathrm{pH}$. (a) $\mathrm{pH}=9$, (b) $\mathrm{pH}=10$, (c) $\mathrm{pH}=11$, (d) $\mathrm{pH}=12$.

pH over 11 , the surface of $\mathrm{Cu}_{2} \mathrm{O}$ coatings shows prism geometry, and the $\mathrm{Cu}_{2} \mathrm{O}$ particles become large as $\mathrm{pH}$ increases.

The XRD patterns of $\mathrm{Cu}_{2} \mathrm{O}$ foam electrodes deposited at various bath $\mathrm{pH}$ are investigated (Fig. 3). The peaks at $43.4^{\circ}$, $50.5^{\circ}$ and $74.1^{\circ}$ can be indexed to $\mathrm{Cu}(111)$, (200) and (222) facets; the peaks at $29.8^{\circ}, 37.4^{\circ}, 50.8^{\circ}$ and $61.8^{\circ}$ can be indexed to cuprite $\mathrm{Cu}_{2} \mathrm{O}(110)$, (111), (200) and (220) facets, and a very strong peak at $37.4^{\circ}$ indicates the preferential growth along (111) facet.

At lower bath $\mathrm{pH}(<7)$, due to the reduction of $\mathrm{Cu}_{2} \mathrm{O}$, metallic $\mathrm{Cu}$ may occur (eqn (2))..$^{\mathbf{1 8 , 1 9}}$

$$
\mathrm{Cu}_{2} \mathrm{O}+2 \mathrm{e}+2 \mathrm{H}^{+} \rightarrow 2 \mathrm{Cu}+\mathrm{H}_{2} \mathrm{O}
$$

However, at higher bath $\mathrm{pH}$ and lower deposition potential (below $-0.6 \mathrm{~V} v$ s. SCE), the reduction of $\mathrm{Cu}_{2} \mathrm{O}$ is forbidden. ${ }^{18,19}$ Since all deposition experiments have been carried out at higher bath $\mathrm{pH}$ in this study, there is less possibility to form metallic $\mathrm{Cu}$ in the electrodeposition of $\mathrm{Cu}_{2} \mathrm{O}$ coatings. In order to verify that no metallic $\mathrm{Cu}$ produces in the electrodeposition, $\mathrm{Cu}_{2} \mathrm{O}$

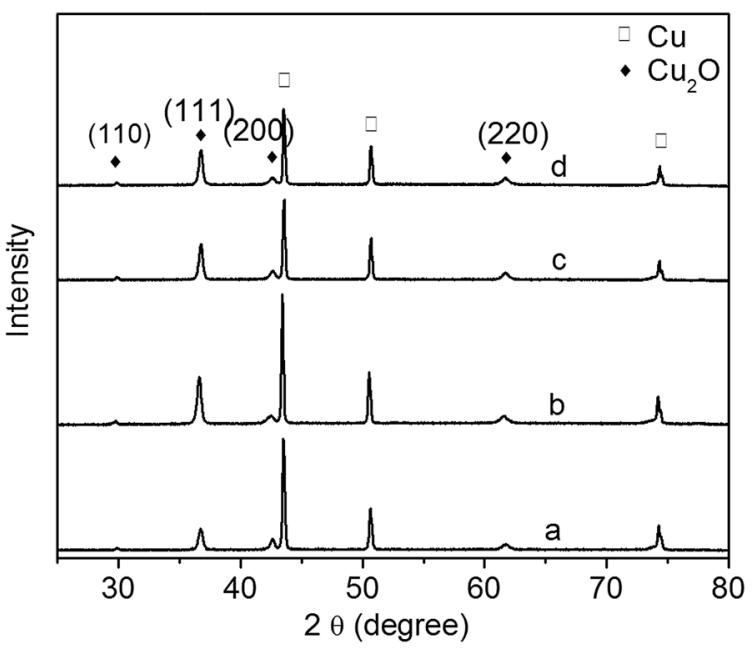

Fig. 3 XRD patterns of $\mathrm{Cu}_{2} \mathrm{O}$ foam electrodes from electrodeposition solution of various bath $\mathrm{pH}$. (a) $\mathrm{pH}=9$, (b) $\mathrm{pH}=10$, (c) $\mathrm{pH}=11$, (d) $\mathrm{pH}=12$. thin films have been electrodeposited on indium tin oxide conductive glass instead of copper foam substrate, and no diffraction peaks of metallic $\mathrm{Cu}$ are detected for the thin films. Therefore the diffraction peaks of metallic $\mathrm{Cu}$ are resulted from copper foam substrate.

It has been reported that the preferential facet depends on bath $\mathrm{pH}$ : the preferential facet is (200) facet at $\mathrm{pH}$ below 9, while it becomes (111) facet at $\mathrm{pH}$ above $9 .{ }^{20}$ In the present study, due to the higher $\mathrm{pH}$, all of the samples have the preferential facet of (111). There are two forms of $\mathrm{Cu}(\mathrm{II}),\left[\mathrm{Cu}(\mathrm{OH})_{n}\right]^{2-n}$ and $\left[\mathrm{Cu}(\mathrm{LA})_{n}\right]^{2-n}$, existing in a basic solution: $\left[\mathrm{Cu}(\mathrm{LA})_{n}\right]^{2-n}$ dominates at lower $\mathrm{pH}$, and $\left[\mathrm{Cu}(\mathrm{OH})_{n}\right]^{2-n}$ dominates at higher $\mathrm{pH}^{21}$ It is therefore concluded that $\left[\mathrm{Cu}(\mathrm{OH})_{n}\right]^{2-n}$ promotes the crystal growth along (111) facet.

The diffraction peak intensity of $\mathrm{Cu}_{2} \mathrm{O}(111)$ facet is bath $\mathrm{pH}$ dependent (Fig. 3). The peak becomes strong when pH goes up from 9 to 10, indicating that more $\{111\}$ facets exposed on the surface are formed; ${ }^{22}$ however, it becomes weak gradually at $\mathrm{pH}$ above 10. The relationship of $\mathrm{Cu}_{2} \mathrm{O}$ grain size to bath $\mathrm{pH}$ is shown in Table 1 . The grain size varies between 24 and $28 \mathrm{~nm}$, and it becomes large as $\mathrm{pH}$ increases. This is because grain size is related to the preferred orientation, and the preferred orientation is $\mathrm{pH}$ dependent. ${ }^{20,23}$

Fig. 4 shows the UV-vis spectra and bandgap of $\mathrm{Cu}_{2} \mathrm{O}$ foam electrodes deposited at various bath $\mathrm{pH}$. All of $\mathrm{Cu}_{2} \mathrm{O}$ foam electrodes exhibit strong absorbance in the visible light range, especially in 400-550 $\mathrm{nm}$ range. Roughly speaking, the

Table 1 Relationship of $\mathrm{Cu}_{2} \mathrm{O}$ grain size to deposition bath $\mathrm{pH}$

\begin{tabular}{ll}
\hline Bath $\mathrm{pH}$ & Grain size (nm) \\
\hline 9 & 24.82 \\
10 & 26.46 \\
11 & 26.87 \\
12 & 27.47
\end{tabular}

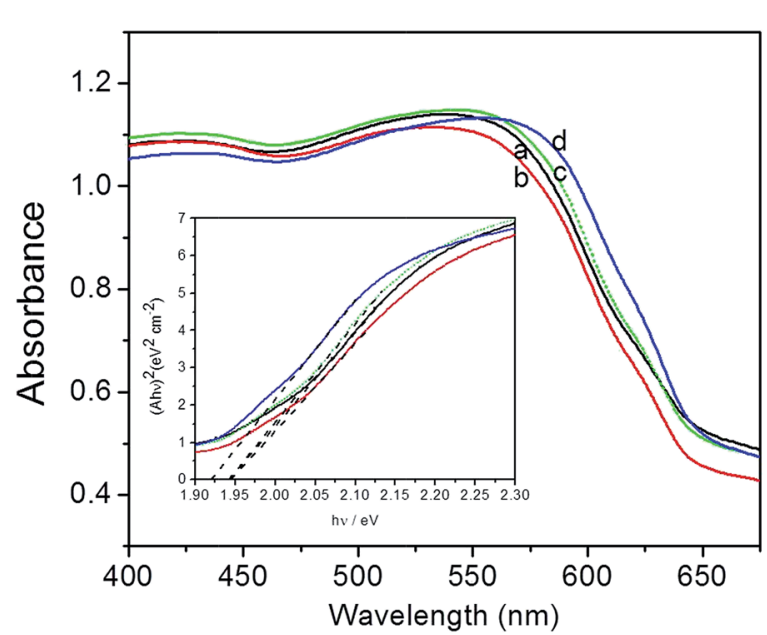

Fig. 4 UV-vis spectra and bandgap (inset) of $\mathrm{Cu}_{2} \mathrm{O}$ foam electrodes from various bath $\mathrm{pH}$. (a) $\mathrm{pH}=9$, (b) $\mathrm{pH}=10$, (c) $\mathrm{pH}=11$, (d) $\mathrm{pH}=12$. 


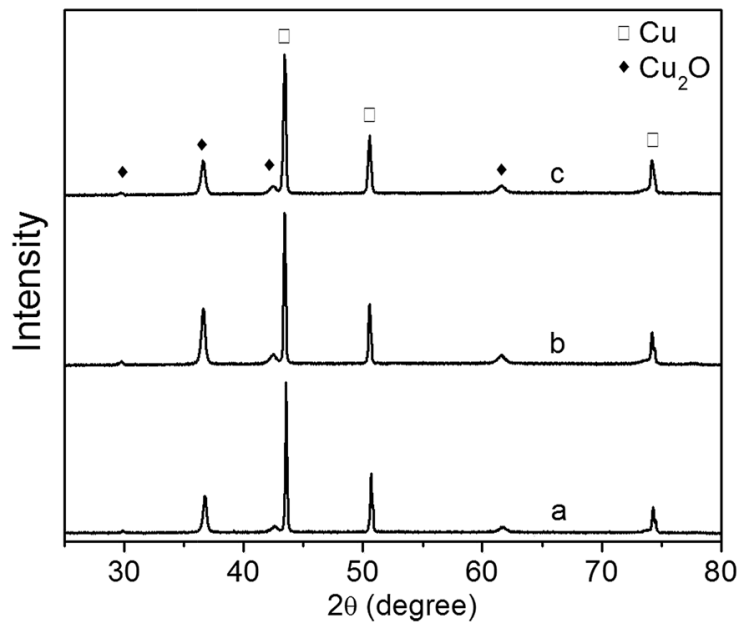

Fig. 5 XRD patterns of $\mathrm{Cu}_{2} \mathrm{O}$ foam electrodes electrodeposited at various deposition time. (a) $10 \mathrm{~min}$, (b) $20 \mathrm{~min}$, (c) $30 \mathrm{~min}$.

absorbance edge and the bandgap (1.94-1.92 eV) remains unchanged as bath $\mathrm{pH}$ increases.

The XRD patterns of $\mathrm{Cu}_{2} \mathrm{O}$ foam electrodes electrodeposited at various deposition time are shown in Fig. 5. All samples show the preferential growth along (111) facet. Compared to the samples deposited for 10 and $30 \mathrm{~min}$, the sample deposited for 20 min exhibits the stronger diffraction peak of $\mathrm{Cu}_{2} \mathrm{O}(111)$ facet, indicating that more $\{111\}$ facets exposed on the surface are formed. ${ }^{22}$ The grain size of $\mathrm{Cu}_{2} \mathrm{O}$ coatings increases from $25.48 \mathrm{~nm}$ for $10 \mathrm{~min}$ to $26.89 \mathrm{~nm}$ for $30 \mathrm{~min}$.

Mott-Schotty plot of $\mathrm{Cu}_{2} \mathrm{O}$ foam electrode electrodeposited for $20 \mathrm{~min}$ at bath $\mathrm{pH} 10$ is shown in Fig. 6. The flat band potential is calculated to be $0.05 \mathrm{~V}$ ( $v s$. SCE). In addition, the slope of the linear portion is associated with the conductivity type of the $\mathrm{Cu}_{2} \mathrm{O}$ coatings. The negative slope indicates that the conductivity of the $\mathrm{Cu}_{2} \mathrm{O}$ coatings is p-type. For p-type semiconductors, the flatband potential is roughly equal to its valence band potential; therefore, the potentials of conduction band

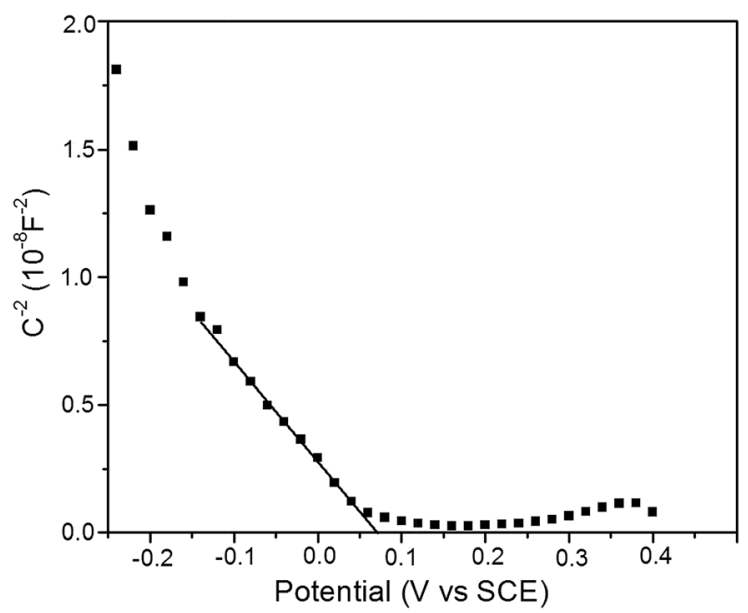

Fig. 6 Mott-Schotty plot of $\mathrm{Cu}_{2} \mathrm{O}$ foam electrode electrodeposited for $20 \mathrm{~min}$ at $\mathrm{pH} 10$.

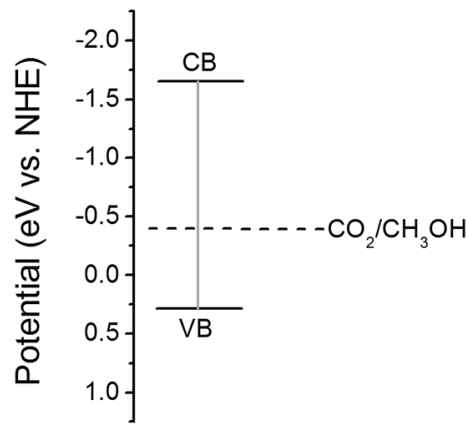

Fig. 7 Band structure in $\mathrm{Cu}_{2} \mathrm{O}$ coatings.

and valence band are calculated to be -1.64 and $0.29 \mathrm{eV}$ ( $v s$. normal hydrogen electrode, NHE), respectively. The band structure in $\mathrm{Cu}_{2} \mathrm{O}$ coatings is schemed in Fig. 7. Since the conduction band potential of $\mathrm{Cu}_{2} \mathrm{O}$ coatings is more negative than the reduction potential of $\mathrm{CO}_{2}$ to methanol, $\mathrm{Cu}_{2} \mathrm{O}$ coatings

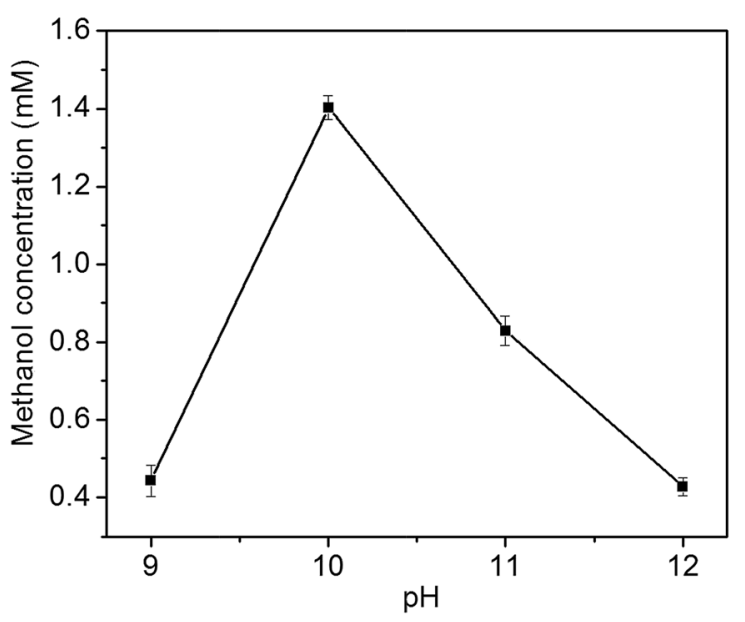

Fig. 8 Effect of bath $\mathrm{pH}$ on methanol concentration.

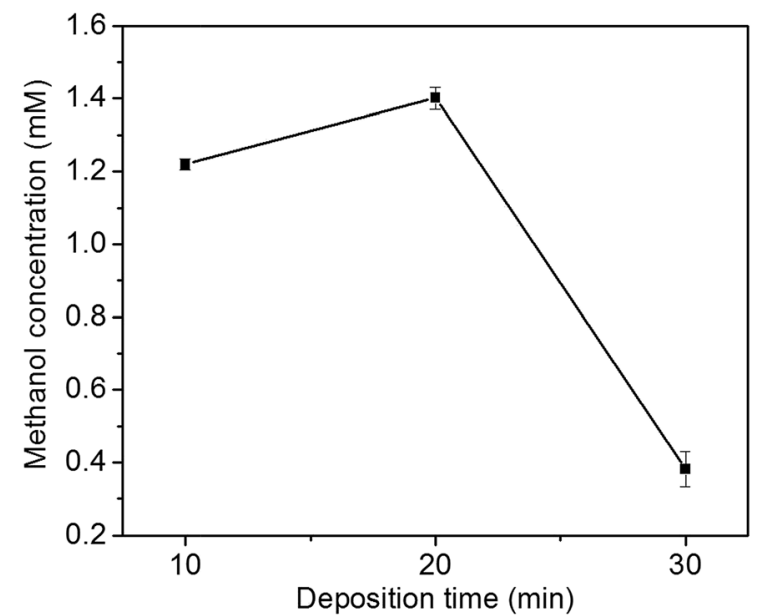

Fig. 9 Effect of $\mathrm{Cu}_{2} \mathrm{O}$ foam electrodes electrodeposited for various deposition time on methanol concentration. 
should have the photocatalytic ability for reducing $\mathrm{CO}_{2}$ to methanol.

\subsection{Photoelectrocatalytic reduction of $\mathrm{CO}_{2}$}

In the liquid product of photoelectrocatalytic reduction of $\mathrm{CO}_{2}$, only methanol is detected by GC-MS in this study. In contrast, ethanol, formic acid, formaldehyde, propanol, acetic acid and methanol is obtained at $\mathrm{Cu}_{2} \mathrm{O}$ cathode by Yadav et al. ${ }^{24}$ The different products might be resulted from the different preferential growth facets of $\mathrm{Cu}_{2} \mathrm{O}$ electrode: methanol is the major product at $\mathrm{Cu}_{2} \mathrm{O}\{111\}$ facet, while ethanol is the major product at $\mathrm{Cu}_{2} \mathrm{O}\{100\}$ facet. ${ }^{24}$

The photoelectrocatalytic performance of $\mathrm{Cu}_{2} \mathrm{O}$ foam electrodes is dependent on electrodeposition bath pH (Fig. 8). Methanol concentration increases with bath $\mathrm{pH}$ from 9 to 10 , and reach a maximum at bath $\mathrm{pH} 10$, then decreases with bath $\mathrm{pH}$ from 10 to 12 . The behaviour of photoelectrocatalytic performance over bath $\mathrm{pH}$ is similar to that of $\mathrm{Cu}_{2} \mathrm{O}(111)$ peak intensity over bath $\mathrm{pH}$ (Fig. 3), indicating that the photoelectrocatalytic performance of $\mathrm{Cu}_{2} \mathrm{O}$ foam electrodes depends largely on exposed $\mathrm{Cu}_{2} \mathrm{O}\{111\}$ facets. It has been suggested that $\mathrm{Cu}_{2} \mathrm{O}$ can stabilize reaction intermediates of $\mathrm{CO}_{2}$ reduction, methoxy adsorbates $\left(\mathrm{H}_{3} \mathrm{CO}^{-}-\right)$, and the unsaturated oxygen atoms at $\mathrm{Cu}_{2} \mathrm{O}\{111\}$ facets act as hydrogen donor sites in $\mathrm{CO}_{2}$ reduction, ${ }^{25,26}$ then $\mathrm{Cu}_{2} \mathrm{O}\{111\}$ facets favour hydrogen addition to the oxygen atom of $\mathrm{H}_{3} \mathrm{CO}^{-}$- adsorbate rather than carbon atom; ${ }^{\mathbf{1 4}}$ therefore, methanol is formed.

The effect of $\mathrm{Cu}_{2} \mathrm{O}$ foam electrodes deposited for various deposition time on methanol concentration is shown in Fig. 9. Compared to those deposited for 10 and $30 \mathrm{~min}, \mathrm{Cu}_{2} \mathrm{O}$ foam electrodes deposited for 20 min gives the optimum methanol concentration $(1.41 \mathrm{mM})$ within $1.5 \mathrm{~h}$. It might be associated with more exposed $\mathrm{Cu}_{2} \mathrm{O}\{111\}$ facets for the electrode deposited for $20 \mathrm{~min}$ (Fig. 5).

The relationship of methanol concentration to the applied potential is presented in Fig. 10a. Methanol concentration increases from 0.26 to $1.41 \mathrm{mM}$ with the increase of the applied potential from -1.1 to $-1.5 \mathrm{~V}$, then decreases with the increase of the applied potential from -1.5 to $-1.7 \mathrm{~V}$. The faradaic
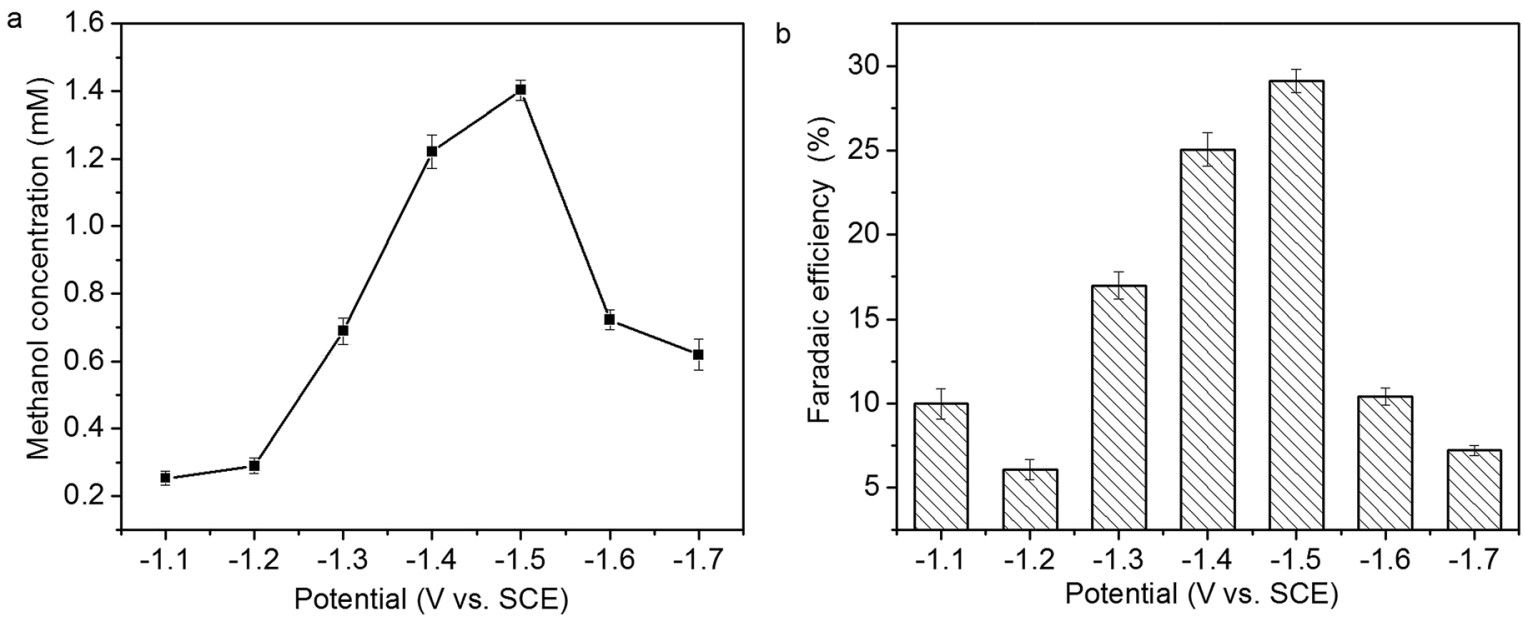

Fig. 10 Relationship of (a) methanol concentration and (b) faradaic efficiency of methanol formation to the applied potential.
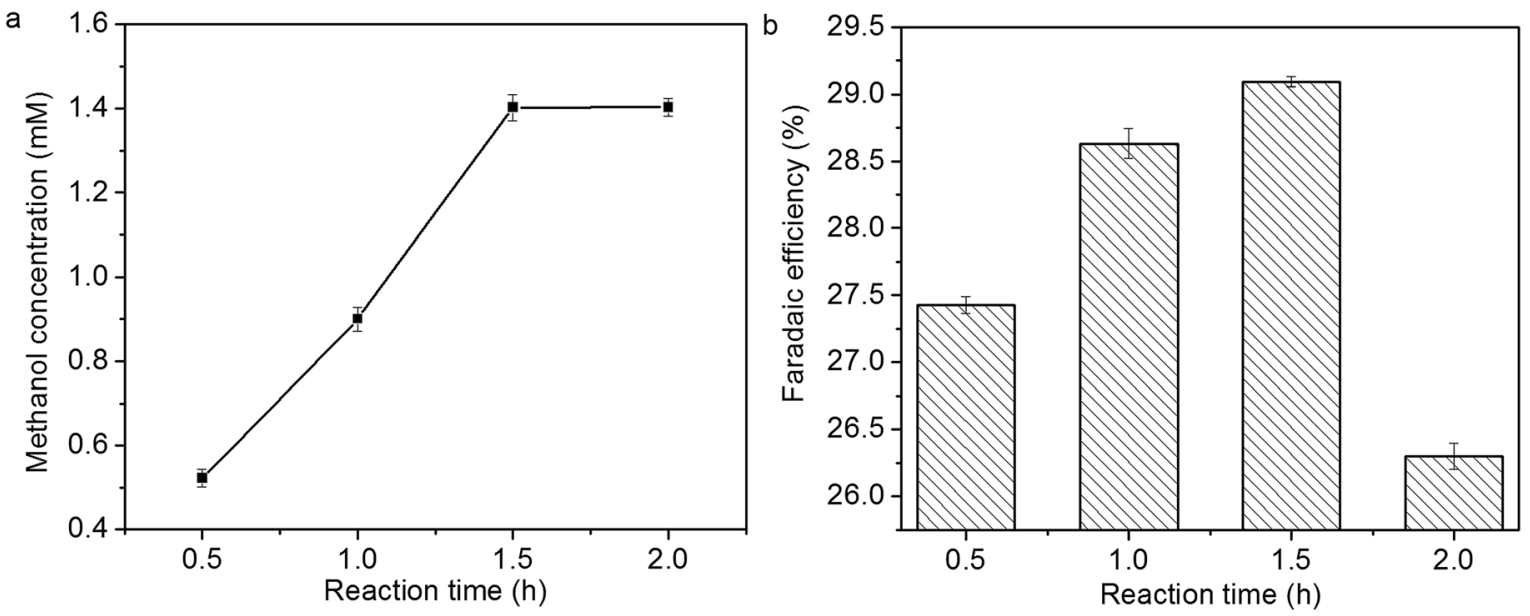

Fig. 11 Influence of reaction time on (a) methanol concentration and (b) faradaic efficiency of methanol formation. 
efficiency of methanol formation at various applied potential is presented in Fig. 10b. The highest faradaic efficiency, 29.1\%, is achieved at $-1.5 \mathrm{~V}$. In addition to methanol, hydrogen gas and $\mathrm{CO}$ are also formed in $\mathrm{CO}_{2}$ reduction. The decrease of methanol concentration and faradaic efficiency of methanol formation at higher applied potential might be attributed to hydrogen evolution reaction and/or $\mathrm{Cu}_{2} \mathrm{O}$ reduction. ${ }^{\mathbf{1 4 , 1 5}}$

The influence of reaction time on methanol concentration and faradaic efficiency of methanol formation is shown in Fig. 11a and b. Methanol concentration increases linearly within $1.5 \mathrm{~h}$, then it levels off. The faradaic efficiency of methanol formation also increases within $1.5 \mathrm{~h}$; however, it decreases over $1.5 \mathrm{~h}$, which might be due to the deactivation of $\mathrm{Cu}_{2} \mathrm{O}$ coating:s. ${ }^{\mathbf{1 4 , 1 5}}$

In previous study, the activity of $\mathrm{Cu}_{2} \mathrm{O}$ electrodes derived from electrodeposition and air oxidation decreases suddenly, and methanol formation diminishes over 30 min. ${ }^{\mathbf{1 4}}$ In this study, the stability of $\mathrm{Cu}_{2} \mathrm{O}$ foam electrodes are improved, and a high formation rate of methanol $\left(23.5 \mu \mathrm{mol} \mathrm{cm}{ }^{-2} \mathrm{~h}^{-1}\right)$ can be obtained within $1.5 \mathrm{~h}$.

The morphology of $\mathrm{Cu}_{2} \mathrm{O}$ foam electrode surface during photoelectrocatalytic reaction is examined as shown in Fig. 12. Compared to the as-prepared foam electrode, the electrode surface becomes rough and many fine particles occur after
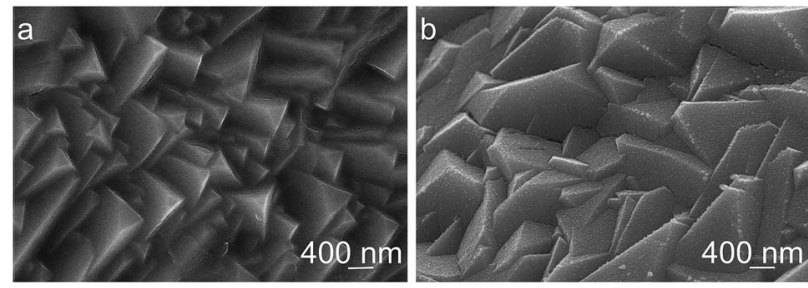

Fig. 12 Morphology of $\mathrm{Cu}_{2} \mathrm{O}$ foam electrodes surface during photoelectrocatalytic reaction. (a) Before reaction, (b) after reaction for $1.5 \mathrm{~h}$.

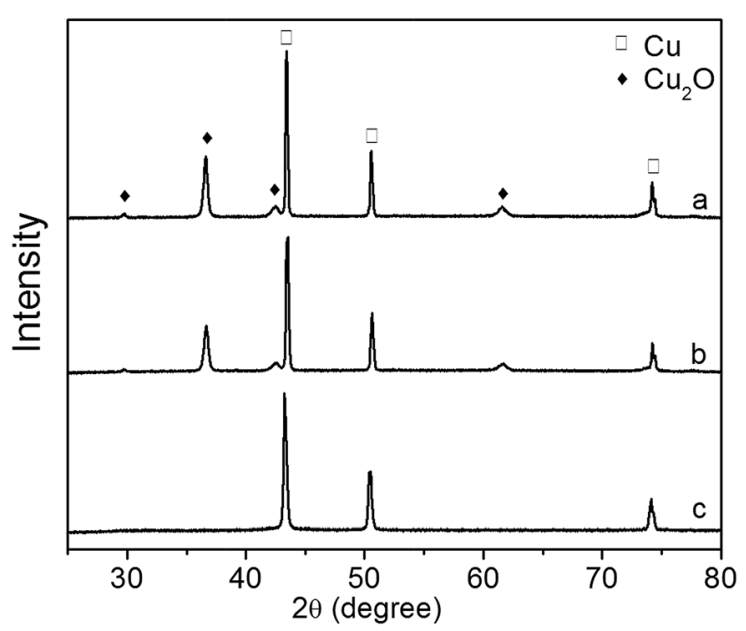

Fig. $13 \mathrm{XRD}$ patterns of $\mathrm{Cu}_{2} \mathrm{O}$ foam electrodes during photoelectrocatalytic reaction. (a) Before reaction, (b) after reaction for $0.5 \mathrm{~h}$, (c) after reaction for $1.5 \mathrm{~h}$. photoelectrocatalytic reaction, and the fine particles become large with reaction time.

The XRD patterns of $\mathrm{Cu}_{2} \mathrm{O}$ foam electrodes before and after photoelectrocatalytic reaction are presented in Fig. 13. The $\mathrm{Cu}_{2} \mathrm{O}(111)$ peak becomes weak at $0.5 \mathrm{~h}$, and disappears at $1.5 \mathrm{~h}$, indicating that $\mathrm{Cu}_{2} \mathrm{O}$ is gradually reduced during photoelectrocatalytic reaction.

\section{Conclusions}

The $\mathrm{Cu}_{2} \mathrm{O}$ foam electrodes have been fabricated by electrodeposition of $\mathrm{Cu}_{2} \mathrm{O}$ coatings on copper foam substrate. They have three-dimensional coaxial structure. At bath $\mathrm{pH}$ 9-12, cuprite $\mathrm{Cu}_{2} \mathrm{O}$ coatings can be obtained with (111) facet as the preferential growth facet, and $\mathrm{Cu}_{2} \mathrm{O}$ grain become larger with increasing $\mathrm{pH}$. All of $\mathrm{Cu}_{2} \mathrm{O}$ foam electrodes exhibit strong absorbance in the visible light range, especially in 400-550 $\mathrm{nm}$ range. The resulted $\mathrm{Cu}_{2} \mathrm{O}$ foam electrodes show photoelectrocatalytic performance on the reduction of $\mathrm{CO}_{2}$ to methanol. The $\mathrm{Cu}_{2} \mathrm{O}$ foam electrodes deposited at bath $\mathrm{pH} 10$ for $20 \mathrm{~min}$ have higher intensity of (111) diffraction peak, and exhibit higher catalytic activity, indicating that photoelectrocatalytic performance of $\mathrm{Cu}_{2} \mathrm{O}$ foam electrodes depends largely on exposed $\mathrm{Cu}_{2} \mathrm{O}\{111\}$ facets. At the applied potential of $-1.5 \mathrm{~V}$ ( $v s$. SCE), the optimum methanol concentration and the faradaic efficiency of methanol formation are obtained within $1.5 \mathrm{~h}$, and they are $1.41 \mathrm{mM}$ and $29.1 \%$, respectively. The formation rate of methanol achieves $23.5 \mu \mathrm{mol}$ $\mathrm{cm}^{-2} \mathrm{~h}^{-1}$ within $1.5 \mathrm{~h}$. The gradual reduction of $\mathrm{Cu}_{2} \mathrm{O}$ leads to the deactivation of $\mathrm{Cu}_{2} \mathrm{O}$ foam electrodes.

\section{Acknowledgements}

We gratefully acknowledge National Natural Sciences Foundation of China (Grant No. 21676010) for financial support.

\section{Notes and references}

1 B. Kumar, M. Liorente, J. Froehlich, T. Dang, A. Sathrum and C. P. Kubiak, Annu. Rev. Phys. Chem., 2012, 63, 541.

2 J. C. S. Wu, H.-M. Lin and C.-L. Lai, Appl. Catal., A, 2005, 296, 194.

3 P.-W. Pan and Y.-W. Chen, Catal. Commun., 2007, 8, 1546.

4 C. W. Tsai, H. M. Chen, R.-S. Liu, K. Asakura and T. Chan, J. Phys. Chem. C, 2011, 115, 10180.

5 J. Qiao, Y. Liu, F. Hong and J. Zhang, Chem. Soc. Rev., 2014, 43, 631.

6 K. P. Kuhl, E. R. Cave, D. N. Abram and T. F. Jaramillo, Energy Environ. Sci., 2012, 5, 7050.

7 M. Gattrell, N. Gupta and A. Co, J. Electroanal. Chem., 2006, $594,1$.

8 D. Canfield and K. W. Frese Jr, J. Electrochem. Soc., 1983, 130, 1772.

9 D. P. Summers, S. Leach and K. W. Frese Jr, J. Electroanal. Chem. Interfacial Electrochem., 1986, 205, 219.

10 A. Bandi, J. Electrochem. Soc., 1990, 137, 2157.

11 J. P. Popic, M. L. Avramov-Ivic and N. B. Vukovic, J. Electroanal. Chem., 1997, 421, 105. 
12 N. Spataru, K. Tokuhiro, C. Terashima, T. N. Rao and A. Fujishima, J. Appl. Electrochem., 2003, 33, 1205.

13 J. Qu, X. Zhang, Y. Wang and C. Xie, Electrochim. Acta, 2005, 50, 3576.

14 M. Le, M. Ren, Z. Zhang, P. T. Sprunger, R. L. Kurtz and J. C. Flake, J. Electrochem. Soc., 2016, 158, E45.

15 J. Albo, A. Sáez, J. Solla-Gullón, V. Montiel and A. Irabien, Appl. Catal., B, 2013, 176-177, 709.

16 J. Yuan and C. Hao, Sol. Energy Mater. Sol. Cells, 2013, 108, 170.

17 J. Yuan, L. Zheng and C. Hao, RSC Adv., 2014, 4, 39435.

18 Y. Zhou and J. A. Switzer, Scr. Mater., 1998, 38, 1731.

19 Y. C. Zhou and Y. A. Switzer, Mater. Res. Innovations, 1998, 2, 22.
20 S. S. Jeong, A. Mittiga and E. Salza, Electrochim. Acta, 2008, 53, 2226.

21 R. Portanova, L. H. J. Lajunen and M. Tolazzi, Pure Appl. Chem., 2003, 75, 495.

22 L. Wang, R. Zhang, T. Zhou, Z. Lou, J. Deng and T. Zhang, Sens. Actuators, B, 2017, 239, 211.

23 C. D. Lokhande and S. H. Pawar, Phys. Status Solidi A, 1989, $111,17$.

24 V. S. K. Yadav and M. K. Purkait, Energy Fuels, 2015, 29, 6670.

25 D. F. Cox and K. H. Schulz, J. Vac. Sci. Technol., A, 1990, 8, 2599.

26 S. Bailey, G. F. Fronment, J. W. Snoeck and K. C. Waugh, Catal. Lett., 1995, 30, 99. 